\title{
The Quality of Deliberation in Two Committees of the European Parliament: The Neglected Influence of the Situational Context and the Policymaking Stage
}

\author{
Léa Roger* and Gary S. Schaal \\ Department of Political Sciences, Helmut Schmidt University/University of the Federal Armed Forces Hamburg, \\ Holstenhofweg 85, 22043 Hamburg, Germany; E-Mails: lea.roger@hsu-hh.de (L.R.); \\ gschaal@hsu-hh.de (G.S.S.); Tel.: +49 4065412785 (L.R.); Fax: +49 4065413370 (L.R.) \\ * Corresponding author
}

Submitted: 1 August 2013 | Accepted: 29 August 2013 | Published: 9 October 2013

\begin{abstract}
In our paper we try to answer two empirical research questions. First, we assess the deliberative quality of discussions in two committees of the EU Parliament. In order to do so, we use a slightly revised version of the DQI. Second, we identify and empirically measure those variables that systematically influence the quality of deliberation in interviews with debate actors. We argue that the quality of deliberation in EU committees is influenced by two normative values: deliberation (common good orientation) and responsiveness (particular interest orientation), with the guiding value determined by the particular situation. Using a multidimensional concept of deliberation, we empirically test the impact of situational variables on specific aspects of deliberative quality. In addition, we take into account the temporal dimension of deliberation.
\end{abstract}

Keywords: committees; deliberation; European Parliament; responsiveness

\section{Introduction}

The theory of deliberative democracy is the most important strand of democratic thought today [1]. Its promise of greater legitimacy and better deliberative decision-making has achieved much attention in political practice. Empirical deliberation research aims at measuring the deliberative quality of communication. Since it is nearly impossible to measure deliberation in non-institutionalized, real-world situations [2], almost all studies analyze deliberation in institutionalized contexts. The most relevant institutionalized communication context in politics is parliament. Regarding parliament as the normative locus of deliberation has a long history in political theory and the history of ideas [3], which is why most studies address the variables that influence the quality of deliberation in parliamentary debates.

In this paper, we empirically analyze the deliberative quality of debates in two committees of the EU Parliament. We chose to analyze debates in the committees of the EU Parliament because committees are the main locus of deliberation (if deliberation takes place at all). We chose the EU Parliament because, unlike the case in national parliaments, members must cooperate as they search for a common policy beyond. Deliberation in EU committees can therefore be expected to be higher than in national parliamentary 
committees. Using the DQI [4] we analyze the debate in the Monetary and Economic Affairs Committee (ECON) on the "two-pack" legislative proposals for European economic governance. We further analyze a joint debate in the Committee on Civil Liberties, Justice and Home Affairs (LIBE) and the Committee on Women's Right and Gender Equality (FEMM) on a directive regarding the rights, support and protection of victims of crime.

We argue that two sets of variables-situational variables and temporal variables-systematically influence the quality of deliberation in committee debates in the EU Parliament. Situational variables describe the social aspects of a political decision; temporal variables describe the particular stage of the policymaking process. The importance of these variables has been widely neglected in recent research [5].

To develop our argument, we first lay down the theoretical background and the methods used in our analysis (2). Qualitative interviews were held with members of the EU Parliament regarding the importance of the situational variables in the "two-pack" and the "directive on minimum standards on the rights, support and protection of victims of crime" $[6,7]$. The key findings of these interviews are presented in part (3). The quality of deliberation in the two committees has been analyzed using a slightly modified version of the DQI. The findings are discussed in section (4). The final section sums up the key findings of the empirical study (5).

\section{Discussion of Concepts}

\subsection{Deficits of Current Debates on Parliamentary Deliberation}

It is common to think of parliamentary deliberation normatively: the best mode of communication in a parliament. But there is no overarching basic principle (idée directice) normatively guiding the work and the corresponding mode of communication of a representative. Rather, communication in parliament has two underlying normative ideals: search for the common good and responsive representation. Both basic ideas are normatively compelling and belong to two different strands of political thought. Both serve as implicit or explicit normative guidelines for the communicative behavior of a representative. Hence, the analysis of the parliamentary debates has to take into account which basic principle actually guides a representative. A comprehensive evaluation of deliberative quality has to utilize two different benchmarks: a theoretical one grounded in the theory of deliberation and communicative action, and an empirical one, grounded in the subjective understanding of the representatives' work. Deliberation is more likely in committee than in plenary debates, so the former should be the focus of analysis ([8], see [9-11]).

The European theory of deliberation, especially the works of Jürgen Habermas, has paid little attention to the one who is speaking and the problem to be solved. Gutman and Thompson [12] were the first to analyze the problem-solving capacity of deliberation with regard to different kinds of political problems. Drawing on these insights, this paper argues that political problems can systematically hinder or promote deliberation, depending on the specific aspects they present.

The work of Steiner et al. [13] has analyzed the impact of institutional macrostructures on deliberative quality in parliament. What has been neglected so far in empirical deliberation research is the influence of the procedural microstructure of policymaking. We argue that the situation and the particular stage of policymaking in the EU Parliament shape the deliberative quality of the debates.

\subsection{Deliberation}

Within a mere 10 years since prominent thinkers such as Jürgen Habermas [14], Bernand Manin [15], Cass Sunstein [16], Amy Gutmann and Dennis Thompson [12], James Bohman [17], and John Dryzek [18] began to advocate deliberative democracy, the normative political theory gained stunning momentum. Bohman wrote of the "coming of age of deliberative democracy" in 1998 [19] and Simone Chambers judged that this strand of theory entered the stage of a "working theory" in 2004 [20]. Beginning with the turn of the century, deliberative democracy became an empirical theory in at least two ways: first, deliberative modes of decision-making became an increasingly large part of political practice, first in the USA, and then all around the world; second, the empirical analysis of the deliberative quality of communication (empirical deliberation research) gained popularity, even though some authors still cast doubt on the idea that a normative concept can be empirically measured $[21,22]$.

Simply put, normative deliberation occurs when there is a give and take of arguments between persons who consider each other as free and equal and treat each other respectfully. They try to convince others rationally by giving reasons for their arguments and take the arguments of others into account. Deliberative processes are free from any constraints. According to Habermas, the only constraint admitted in a deliberation is the "forceless force of plausible reasons" [14]. Ultimately the mode of communication in a deliberative process is arguing, not bargaining. The normative goal of deliberation is consensus. Taken together, these features of a communication situation constitute an ideal speech situation (see [14]).

Deliberation aims at the common good. After the linguistic turn in political philosophy, the common good is no longer defined in a substantial manner, but merely procedural. Meeting the criteria of an ideal speech situation implies at the same time an orientation towards the common good. Neither a philosopher nor a person participating in a deliberation knows what the 
common good is (in a particular political question) before a deliberation about this concrete political question has taken place.

This normative definition of deliberation has been subject to numerous criticisms (e.g. Sanders [23]). Especially authors from the Anglo-American hemisphere have emphasized that the normative concept of deliberation is so demanding that it cannot even function as a regulatory ideal, since all real-world deliberation falls short of accomplishing the high normative standards put forward by Habermas [14]. Iris Marion Young [24] has argued that rational deliberation is not a neutral form of communication, as rational deliberation is a technique of communication that favors white, middle-class, and educated male speakers. Other modes of communication such as storytelling or greeting are not normatively valued, which discounts their speakers and leads to systematic distortions within rational deliberations.

For the longest time, the differentia specifica of deliberation has been the use of arguments. It was clear that if bargaining occurred or self-interests played a major role during communication, there was no deliberation. But this line has blurred, at least since the now famous article by Mansbridge et al. [25]. The team of authors introduced self-interests as a legitimate part of deliberation, and even though this suggestion has been criticized for stretching the concept of deliberation too far, it was widely received. Taking into account the arguments advanced, Bächtiger et al. [26] propose to differentiate two types of deliberation: Type I deliberation, characterized by the Habermasian logic of communicative action aimed to reach a consensus in rational discourse via the "unforced force of the better argument"; and Type II deliberation that includes other forms of communication, such as storytelling, rhetoric, or even bargaining (Bächtiger et al. [26]). This runs the risk of making deliberation a catch-all concept, with the "concept stretching" (see [27]) creating conceptual blurriness. If even bargaining and self-interest are included, how shall we distinguish discourse from other forms of communication? As Bächtiger et al. ([26], p. 48) write: "almost all communicative act may qualify as 'deliberative'" (see also [28]).

\subsection{Representation}

There are two normative ideals of representation, a deliberative and a liberal one. Both are compelling and none is ethically superior. Historically, both idées directrices have influenced the work and self-understanding of parliamentary representatives, and continue to do so today. Hence, an empirical analysis of the deliberative quality of parliamentary debate must refrain from narrowing the normative scope to just one idée directrice but should embrace the normative pluralism found across parliaments.

From a deliberative perspective, the durational ex- change of arguments makes up the normative heart of parliamentary decision-making [14]. Through the give and take of rational arguments, deliberation is expected to produce more consensual, epistemologically improved outcomes. For Habermas, deliberation sets the sovereignty of the people "communicatively aflow" ([14], p. 486). Older studies see deliberation as the benchmark for ideal parliamentary communication (see $[13,14])$. But recent works have positioned deliberation as one of many forms of parliamentary communication ranging from bargaining (even with threats and promises) to high-level deliberative debate (see $[25,26])$.

From a liberal point of view, the normative idea of representative democracy is responsiveness ([29,30]). This rests on the premises that every person is the best judge of his or her own interests; departing from the expressed preferences of citizens would deprive them of their autonomy and could lead to morally inferior forms of paternalistic government. In spite of this, most strands of liberal theory value a free mandate ([31]; summarized in [32]). Accordingly, the normative ideals of representation in parliament oscillate between mere representations of citizen preferences and free deliberation in search for the common good. Deliberative quality in parliament depends not only on institutional variables but also on the two basic principles of representation (deliberation and responsiveness) and their interaction with the self-understanding of representatives.

\subsection{Conceptual Framework}

Drawing on the basic ideas of Gutman and Thompson [12] we are convinced that specific aspects of a political problem can influence the communicative behavior of representatives systematically and hence impact on deliberative quality. We argue that these aspects are not of substantial or essential nature; rather, they are socially and communicatively constructed [33].

To explain the communicative behavior of representatives, it is necessary to specify the basic assumptions of the underlying theory of action. We make two modest basic assumptions that avoid the excessive demands of normativity. First, the prime concern of a representative is reelection. Reelection depends on the electorate's vote, and responsiveness to electorate preferences is the key for reelection. Following research on the principal-agent problem, we regard the responsiveness of a representative as a question of power, monitoring and transparency (see [34-36]). The more power a principal has, the better the ability to monitor the agent's actions; and the greater the transparency of political interaction, the more responsive the representative will be (see [37]). The second assumption is that representatives are not rational actors in a Downsian sense (see [38]). They are believed to be responsive to the electorate's preferences, but they retain their own political preferences and goals. 
Building on these insights, we argue that socially constructed aspects of a political decision systematically influence the representative's ability to deliberate in a committee debate. Three elements are of major importance: the perceived salience of the topic; the perceived publicity of the topic; the perceived strength of particular interests involved. We call these variables situational variables. They are directly linked to power, monitoring, and transparency, the preconditions for responsiveness or deliberativeness from a principalagent point of view.

The salience of the topic denotes its importance for the electorate or the political party, as perceived by the representative. Salience strengthens the representative's responsiveness; actors exercise more pressure (power) on their representatives and expect them to follow their preferences; and voters and parties monitor the representative more closely (transparency). This reduces the representative's ability to deliberate, as he or she must fear sanctions (e.g. non-reelection) in case of deviant political (communicative) behavior (see $[13,39])$.

In mainstream deliberative theory, publicity is a key feature of deliberation (see $[15,40]$ ). As private interests cannot be defended in front of a public, publicity fosters high quality deliberation. Representatives face particular audiences, however. In the face of reelection, the more representatives feel observed (transparency), the more likely they are to focus on the interests of their principals (power), resorting to populist arguments in the public sphere at the expense of reasoning. European elections are generally described as "second order elections". On certain topics, however, the public attention increases (e.g. in the Economic crisis). More generally, representatives react to the "perceived publicity", which increases on topics of broad public interest. Once again, the relevant situational variable is the perceived level of publicity (transparency).

Ideally, deliberation strives for the common good: a political solution that is good "for all". But representatives are elected on national lists and accountable only to their voters. When particular interests (regional interests, national interests, party interests) are at stake, deliberation is less likely, as representatives focus on these interests (power, monitoring).

We also take into account the anticipated veto power (veto variable) of the Council on each issue. Researchers have argued that the presence of vetoplayers strengthens pressure to reach agreement. Bächtiger/Hangartner [41] consider veto power as an "enabling constraint" favoring serious argument. Similarly, in their study on deliberation in EP plenary debates, Lord/Tamvaki [42] assume that the presence of the Council will positively influence deliberation in the $\mathrm{EP}$, but the empirical results were ambiguous. The authors found that veto power increases the commongood orientation of MEPs, but found no effect on respect levels and the rationality of argumentation [42]. This paper analyzes the exercise of de facto veto- power. As Fearon [43] shows, states value costs against expected benefits: when benefits are high, they are more likely to hold out until an agreement is found that serves their interests. In this sense, the veto-risk differs from legislative file to legislative file, which is why we assess the variable separately for each case studied.

Drawing on insights by Robert Goodin (see [44]), we argue that in order to analyze the complexity of the deliberative processes, one has to "sequentialize deliberative moments". Deliberative quality changes over the course of a communication. Yet "no political philosopher would expect that communicative rationality is present throughout the entire communication process" ([44], p. 3). A solution to this problem is the sequentialization of communication processes. The idea is that different modes of communication occur in different sequences of a communication process. As Bächtiger et al. point out, the dimensions of communication can be subjected to individual assessment: "a sequential perspective of communication processes not only unravels its dynamic nature, it can also be ideally linked to a conception of discourse types" ([45], pp. 3-4).

In this paper, we consider deliberation to be multidimensional, and examine each aspect of deliberation separately. We take multi-dimensionality into account in the analysis of committee debates, arguing that the situational and temporal variables impact differently on each dimension of deliberation. The situational variables are expected to influence the common-good orientation, respect levels, and the willingness to reach agreement. On issues salient to voters, representatives are more likely to focus on particular interests and are more reluctant to compromise.

With regard to the temporal variable, we assume that different deliberative virtues are displayed at different stages of decision-making. Starting with a common assumption in deliberation theory, we argue that deliberative processes in decision-making pass through three stages in the ideal case ([46], see [4749]). The first stage is mutual understanding. Here people tell each other what their preferences are on a given subject. During this stage of communication, reasons are not necessary, as individual preferences have yet to be challenged. The second stage is justification. Here preferences are challenged, requiring people to give reasons justifying their positions. The final stage is decision-making. In this stage, people must consider the arguments of others to find a compromise. As we will show, these three stages have analogous correlates for decision-making in EU committees. Accordingly, the study also accounts for the temporal dimension of deliberation.

\subsection{Measuring Deliberation}

For our study we analyze two legislative decision-making procedures of the European Parliament. These legislative procedures are similar with respect to the institutional setting but vary with regard to their situation- 
al variables. As we noted already, these variables impact on representatives' communicative behavior as they react to the situation of decision-making and adapt their behavior accordingly. We first analyze qualitative interviews held with members and officials of the European Parliament involved in the decisionmaking process. Second, we compare the quality of deliberation in selected committee debates.

The committee debates are analyzed using the Discourse Quality Index [4], a well-known and uncontested instrument for assessing deliberative quality. The instrument was originally developed and applied to committee debates in three parliaments by Steiner et al. [13], and has since then be applied to various parliamentary and nonparliamentary debates (see $[42,45,50,51])$. This paper uses an extended Discourse Quality Index [52], adapted to parliamentary debates at the European level (see [53,54]).

The DQI measures the quality of deliberation on the basis of speech acts (see Appendix 2 for the Discourse Quality Index). Drawing on Habermas' concept of deliberation, the index is composed of several indicators aimed at assessing the distinctive dimensions of deliberation separately. Since an important element of deliberation is free and equal participation, the indicator participation assesses the speaker's ability to take part in the debate without being interrupted. Deliberation also requires the rational exchange of arguments. Speakers are asked to justify their arguments in light of the "common good". The DQI captures both the quality (level of justification) and the content (common-good orientation) of the arguments made. It assesses how well an argument is justified and if the justification accounts for the best interest of all people concerned. For the purpose of this article, the "common good" is defined as the common interest of all European citizens. A "solidarity" indicator measures whether participants consider the consequences their position has for other people. As Landwehr [55] points out, actors may have particular, non-transferable interests that are not necessarily common to all European citizens. Nevertheless, they may be legitimately articulated in parliamentary debates [25]-as long as they do not hamper the interests of other citizens.

Another central dimension of deliberation is respect. Respect encompasses three dimensions: respect towards other participants during the debate; respect towards demands expressed; and respect towards groups concerned by the policies debated. In the debate, participants are required to listen and reply to each other (interactivity). Since "ideal deliberation aims to arrive at a rationally motivated consensus" ([40], p. 23), participants should be open-minded and consider the merits of each argument. If consensus is not possible, participants should be the willing to reach a compromise (constructive politics). It is important that participants be sincere (veracity). But since the sincerity of a speech cannot be assessed, the indicator is not included in the DQI. The DQI assesses the quality of deliberation that ranges from no deliberation (if the indicators are not fulfilled) to the ideal form of discourse. The individual dimensions are coded separately. Deliberation is considered a multi-dimensional concept. For example, participants can justify their arguments but refer to particular interests, and vice versa. The higher the code assigned to the speech act for each dimension, the better the quality of deliberation is.

Our study measures the impact of two different sets of variables on the quality of deliberation in EU parliaments committees: situational variables and temporal variables (Figure 1) [56].

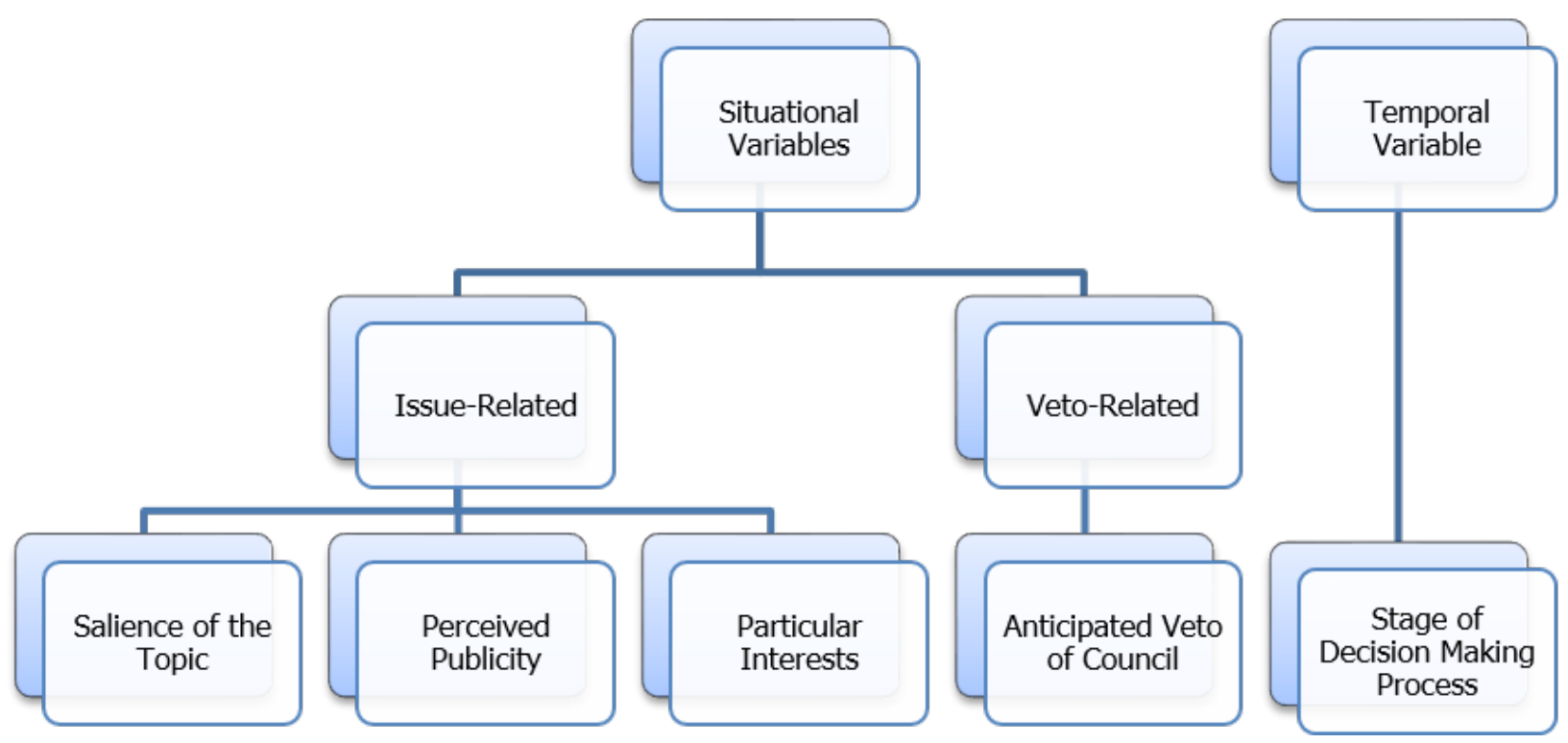

Figure 1. Variables. Source: own illustration. 
The three issue-related situational variables-topic salience, publicity, and interests-can be expected to foster the responsiveness of a representative towards his voters, and thus to negatively impact on his ability to deliberate. Responsive representatives are assumed to be oriented toward particular interests, to be less respectful with regard to the interests of other groups and to be less willing to compromise. The more salient a topic, the higher the perceived publicity, and the more interests at stake, the less likely we are to find common-good orientation, compromise, and respect within a debate.

Deliberative quality is also mediated by the perceived need of unanimity within a political decision (see $[41,55])$. Unanimity increases the political relevance of a decision and the chances of enforcing a political decision vis-à-vis other political actors or institutions. The Council of the European Union may function as a (pseudo) veto player against the European Parliament. In case of conflict, the quality of deliberation in parliament will increase due to the need to agree on a strong common position. Accordingly, the willingness to compromise is expected to increase in case of conflict with the Council.

With regard to the temporal variable, we draw on Goodin's [44] argument that deliberative quality changes over time ("sequentialization"). Deliberative quality can therefore be expected to vary systematically over the course of the ideal decision-making stages. In European Parliament committees, legislative proposals are debated in three stages: exchanges of views, draft reports, and consideration of amendments. The three stages can be seen as analogous to the three stages of deliberation we presented above. Accordingly, the level of interactivity, willingness to compromise and the level of justification increase with every stage.

The first stage aims at exchanging information. Representatives make an initial statement on the legislative proposal without justifying it. In the second stage, the draft reports are presented and discussed, increasing the level of deliberation. The rapporteurs justify their proposals and representatives supply comments and reach provisional compromises. The debate is more interactive, and representatives reply to the rapporteur. At the final stage, amendments are presented and considered at a high level of deliberation. Because this is the last opportunity for representatives to defend their position, compromise becomes central, as this may be the only way to get amendments adopted. The level of interactivity is expected to be high and involve much discussion of proposed amendments [57].

\section{Empirical Part: Analyzing the Situation and the Quality of Deliberation}

The study analyzes the committee debates on two legislative files. Both debates take place in comparable institutional settings-the first reading in parliamentary committees-but differ with regard to the situational variables. The debates take place in three stages, each analyzed separately: the exchange of views, the presentation of draft reports, the consideration of amendments. We demonstrate that the quality of deliberation differs in both debates, and at each stage of procedure. We then argue that situational and temporal variables mostly account for these differences.

\subsection{Assessing the Impact of Situational and Temporal Variables}

The analysis focuses on two legislative proposals: a package of two regulations on European economic governance and a directive on victim's rights. The two-pack is made up of two legislative regulations: a proposal on an enhanced economic surveillance of Member States in risky situations and a proposal on a better oversight of economic and budgetary policy. Both proposals were debated together in the Committee on Economic and Monetary Affairs (ECON). The two-pack deals with questions that are at the heart of the debate on economic governance at the European level but that also have important consequences for national budgetary sovereignty. These issues are similar to those regulated by the fiscal compact, adopted by the Member States in March 2012. The two-pack can be considered a highly salient issue in the light of the financial crisis, while the question of European governance has been much debated in the broader public. The legislation is also important for the Council, whose veto-power is expected to be strong.

The directive on victim's rights strengthens the rights of victims in the European Union. The proposal was jointly debated by the Committee on Civil Liberties, Justice and Home Affairs (LIBE), and the Committee on Women's Rights and Gender Equality (FEMM). Unlike the two-pack, the topic is neither salient nor debated in the broader public. The directive also differs from the two-pack regarding the demands and interests at stake. Every European citizen is concerned as a possible future victim, and there are no national or other particular interests involved. Hence, the victims directive is a nonsalient, noncontroversial issue touching common, European interests, in which the vetopower of the Council can be expected to be weak.

Situational variables affect deliberative quality depending on how they are perceived by the participants of deliberation. The representatives are expected to react to the situational variables and to adapt their communicative behavior accordingly. In the next section, we turn to qualitative interviews, and analyze the situational variables as perceived by the participants of debate.

\subsubsection{Situational Variables}

To identify the relevance of situational variables, we conducted qualitative interviews with the main actors of debate [58] (see Appendix 1 for the questionnaire 
and Appendix 3 for the list of interviews). In the European Parliament parliamentary committees are the central loci of decision-making $([59,60])$. Due to increasing workload, the decision-making process has been rationalized and the working load divided among the members ([61]). Within the committee, few rapporteur(s) and shadow rapporteurs are assigned to handle the legislative proposal. The rapporteur is in charge of drafting the report, while the shadow rapporteurs comment on it for their political group. In the debates, speaking time is equally distributed amongst (shadow) rapporteurs, and other members intervene only if there is time left for debate. In our study, qualitative interviews were made with nearly all rapporteurs both on the two-pack and the victims directive. In addition, interviews were made with members of the secretariat, political advisors, and assistants of MEPs working on the legislative proposal [62]. The interviewees were asked to describe the process of decision-making, and to evaluate the salience and publicity of the topic and the role of the Council [63]. The interviews were face-to-face, held in English, French, or German (some of the quotes below are translated), lasted between ten minutes and one hour, and were transcribed and coded in MaxQDA. The results are presented in the following section.

As expected, representatives perceived the two-pack as a very salient issue. In the interviews, the two-pack was qualified as one of the most important pieces of legislation the parliament dealt with at the time of the interviews [64]. The topic raised the attention of noncommittee members as well, and was commonly considered a "hot topic, a politically important topic" [65] both for the political groups and for Member States. Tellingly, the EP leadership paid close attention to the decision-making process and the proposals were discussed at the highest level of hierarchy [66].

Since the beginning of the financial crisis, issues of European governance have dominated public debate. The interviewees agreed that economic questions were at the "spotlight" [67] and often referenced the national public debates on European governance. The committee debate on the two-pack took place during the French election campaign; several interviewees indicated that the campaign was also important for decision-making in the European Parliament [68]:

"There is this campaign Berlin-Paris, so I hope the vote on the two-pack will take place much later. Otherwise, I am afraid it will be very difficultperhaps regardless of the content of the package in the end-for the [party] in this parliament to vote for it, for purely symbolic reasons" [69].

"[The political groups have to] take into account national elections obviously [...] how the national debate is at the moment" [67].

There were strong particular and national demands at stake, as citizens have been directly touched by the crisis. This made it very difficult for representativesespecially for those coming from countries with serious economic problems-to neglect the demands expressed by their voters. As the following statement of an MEP shows, the economic situation of their own Member State was determinant for the political opinion of the representatives:

"I am [Member State] [...] from the point of view of someone who is Greek or Portuguese or Irish and who is perfectly aware about the probability of attaining the objectives of the Troika-it is nearly impossible, even if one wants to attain it, it is impossible-so I have to be against any automatic sanctions [...] In theory, I do prefer economic coordination at the EU level and I am clearly against intergovernmentalism, but from a practical point of view, in a situation of bad economic coordination and where divergences between countries play a role, if I want to be with the weakest, I have to oppose the mechanism of automatic sanctions by the Commission" [70].

In the context of the crisis, national considerations were of major importance to the MEPs and nearly all interviewees mentioned them.

Under these circumstances, representatives are unlikely to deliberate: they are asked to focus on particular interests, and to defend them in the decisionmaking process. Their voters and principals watched them, restraining their action scope in the debate. Against this background, the important risk of being vetoed by the Council is the only situational variable expected to play in favor of deliberation. The Council was concerned that the two-pack may hamper the validity of the treaty and was hence reluctant to include the treaty provisions in the two-pack (as proposed by the rapporteurs):

"[The Member States] fear that the two-pack becomes a reality, it is a regulation, before the intergovernmental treaty would be ratified. [...] When would that be? I don't know. [...] And the Member States are attached to the treaty [...] so it is not in their interest to be flexible in the negotiations if there is something they don't like. They will be able to say, see, one cannot get an agreement with this lousy parliament. So the communitarian method, which obliges us to pass by the parliament, in codecision, delays, is inefficient, so it is better to go with the intergovernmental method" [66].

The European Parliament disagreed with the Council on several points of the proposal, and the MEPs expected severe conflicts in the course of the negotiation process. In such a contentious context, a united EP position was considered to be crucial for strengthening Parliament's position in the negotiation process with the Council:

"If one wants to win, one needs a large majority of the Parliament, so the rapporteur that negotiates 
on behalf of the parliament can rely on the majority. If he is not told that, finally, you represent 30 votes more than the one that acts against you" [66].

From this perspective, compromising became essential for the European Parliament to avoid being overruled by the Council. But the content of the legislative act was highly controversial, and the potential for compromise limited. MEPs admitted the need for a broad agreement, but stressed that they were not willing to compromise at any price [71]. As one official stated:

\begin{abstract}
"When something is so political and ideological as the two-pack, like in the six-pack, if you have to vote against it, you vote against it. You cannot always compromise. Because there is a right-wing majority in the Council and there is a right-wing majority in the Parliament, obviously they are going to get some kind of agreement that fits them. So in that kind of scenario we vote against it" [71]
\end{abstract}

In sum, the issue of economic governance was controversially discussed both at the national and at the European level. MEPs were confronted with different particular demands from their political groups, their Member States, and their voters. In this context, the parliamentary debate took place under situational constraints. MEPs were aware of the salience and publicity of the issue, and accordingly paid high attention to the interest of their voters and their party/ political group. Consequently, they cannot be expected to focus on a common European interest in the debate or to show explicit respect for the demands and interests of other groups. Nevertheless, due to the conflicts with the Council, the veto-risk was important and the debate took place under pressure to reach a common position. The veto-risk strengthened the willingness to compromise, even though an agreement was difficult to reach.

The victims' directive differed from the two-pack regarding the situational variables. First of all, while personally salient to them, the interviewees admitted that the general attention paid to the topic was fairly low. The (shadow) rapporteurs were charged by their groups with handling the legislative proposal, but the groups did not closely follow the decision-making process in the committee [72]. Rather, the political groups were informed by their shadows on the agreement reached in the committee once the compromises between the shadow rapporteurs have been made [73]. The interviewees did not expect much controversy within their groups but expected their groups to follow their voting recommendations and thus were independent of external constraints in the committee debate.

The public attention paid to the topic was also low. The issue was rarely mentioned in the media, and MEPs did not expect the citizens to be aware of the legislative proposal. MEPs did not feel observed by their voters and their principals; rather, they were afraid that the proposal might receive too little attention.
"Groups of opinion and the NGOs will be happy with [the directive] but the particular citizens don't even know what we are working on. [...] If we are talking about a directive, they don't even know what a directive is, what a regulation is, what the Council, the Commission, committees are" [74].

"A majority decided to rush [...] and they are kind of stressed because if you take your time now then nobody is going to be interested in it and then it's going to be stopped" [75].

Unlike the debate on the two-pack, which had particular demands and interests at stake, MEPs were free from external pressures when dealing with the directive. The political groups all agreed on the need to strengthen the rights of victims. As several persons indicated in the interviews, there was a broad consensus on the main points of the directive within the parliament, across all political groups [76].

"In general, there is a total agreement. Of course, there are minor issues where there can be problems [...]. But the most important lines are ok. Great support for victims all around Europe" [77].

"I mean maybe some think that is true that when we are talking about victims it is very difficult that there is not a consensus. Why? Because who is the one who dares to say something against victims?" [74].

With regard to interinstitutional negotiations, the interviewees expected a conflict with the Council on the costs of the directive [78]. In the context of the crisis, Member States aimed at reducing public expenditures. In this perspective, MEPs outlined the need to agree on a common position with a broad majority to strengthen parliaments bargaining power in the negotiation process with the Council [79].

"For instance, the Commission now proposes an individual assessment for victims that I think is very good, which is crucial and I am pretty sure the Council will say that's very costly and who is going to pay for that?" [74].

In sum, the situation of decision-making for the victims directive favored deliberation: the topic was not considered as salient, the public attention paid to it was low, and there were no major national or particular interests at stake. Under these circumstances, MEPs are free to deliberate and may follow their own judgment and focus on a common European interest. They are expected to show respect for each other's interests and the interests of the groups concerned by the policy. In addition, the conflict with the Council is likely to favor MEPs willingness to compromise.

The situational variables are expected to impact on specific dimensions of deliberation, namely the European focus (common good and solidarity), the level of respect, and the willingness to compromise. The two-pack was salient, publicly debated, and involved particular 
interests. By contrast, the victims directive raised no attention in the Parliament, was not debated by the broader public, and aimed at strengthening the rights of victims in Europe. The quality of deliberation on the above-named dimensions can be expected to be higher in the victims directive debate than on the twopack debate.

\subsubsection{Temporal Variables}

As we noted, our study adopts a sequential approach and distinguishes between different stages of decision-making. In the European Parliament a legislative proposal is debated in three stages before the vote in the committee. The temporal variable is expected to impact on three dimensions of deliberation: interactivity, justification, and the willingness to compromise. With regard to these indicators, the overall level of deliberation is expected to increase during the process.

The following section demonstrates that the three stages of decision-making fulfill different functions in the parliamentary decision-making process. Based on the interviews and on statements MEPs made in the committee meetings, this section analyzes the temporal aspect of parliamentary deliberation as perceived by the actors of debate. The next section turns to discourse analysis, in which each stage of debate is separately analyzed.

The main purpose of the exchange of views is to share information. Conversation is aimed at informing the committee members on the legislative proposal and the rapporteur(s) take(s) on the different views the shadow rapporteurs have on the proposal [80]. Though the decision-making has just started and political groups have not necessarily agreed on a strong position [81], the exchange of views allows a first impression of the proposal and the different positions in the parliament.

MEPs are relatively open to discuss the proposal, as they usually have yet to develop a strong opinion on it. MEPs make initial statements on the commission proposal, stating their support or refusal and outlining possible conflicting points:

"I would start by thinking that we need those regulations. [...] There is no question that these can be useful instruments. That said, I will make two comments on [the regulation]" [82].

Given the fact that MEPs tend to make general statements, we expect the level of justification to be lower in the exchange of views than in the following debates. Participants do not necessarily have to justify their position, especially because they have not necessarily developed their own position. Also, the debates are not expected to be very interactive. It is difficult for MEPs to comment on the positions of their colleagues, as they are not always aware of them. Consider this statement: "I would also prefer to wait for the amendments tabled by colleagues to see what we can do with this proposal" [83]. In a similar vein, the orientation towards compromising is expected to be relatively low, as there is simply no need to compromise at this stage of the process.

In the second stage, the rapporteurs present their report (e.g. submit their main propositions to their colleagues) and justify their proposals. The (shadow) rapporteurs are asked to reply to the presentation. The debate is aimed at discussing the legislative proposal in more detail and at exchanging ideas presented by the rapporteurs in their report. As a (shadow) rapporteur outlined in the interview:

"I was starting with the idea that [the topic] needed to be largely debated in the parliament [...] but [the MEPs] should not be constrained by a personal position that they would have taken at the beginning. If you want to open a debate, you have to limit yourself to the presentation of the ideas, but say that you will try to find the best conditions together" [66].

In general, the level of justification is expected to be higher than in the first debate. Rapporteurs need to thoroughly justify their proposals to get support for their reports, and shadow rapporteurs in their committee statements express support for the report, or outline disagreements:

"Then there are some issues that I think need to be very thoroughly analyzed [...]. That is my firm belief. There are some changes made by the rapporteur that I am not sure I can sign off on at this point in time. We need to discuss this and I am sure that will cause a lot of debate further on considering the atmosphere in the Council" [84].

Shadow rapporteurs also use the opportunity to prepare their amendments and focus on the issues that are of main importance to them and their political groups. Since representatives are asked to comment on the earlier proposals by the rapporteur, the level of interactivity is expected to be higher than in the first debate. In addition, representatives explore possible compromises and make initial mediating proposals on the report presented by the rapporteur.

In the last session, the amendments made by shadow rapporteurs are presented and considered. The session on the amendments is commonly considered the most important one:

"I think that the real debate will be on the amendments and the compromise amendments. This will be the real debate" [85].

Indeed, the last debate is of major importance for two reasons. First, the positions of each participantand, via the shadow rapporteurs, of each political group-are publicly presented and openly debated. Second, the debate is the last opportunity for participants to justify their position and to persuade their colleagues and their voters. Accordingly, we assume 
justification to be highest at the last stage of decisionmaking. Compromises are likely to occur as well. In the European Parliament compromise is vital for representatives to get their position included in the final legislative act when there is no clear-cut majority. Shadow rapporteurs outline the points important to them while signaling their support for and/or their disagreement with the report. The purpose is to achieve a compromise in which their interests are included:

"...and I can whole heartily endorse these forty compromise amendments except from two [...]. So compromises two and three are rather unfortunate. I would have preferred them to be worded in a different way, but as I said, apart from that, I am whole heartily behind the rapporteurs' proposals" [86].

Regarding the impact of the temporal variable, we expect the level of deliberation to increase on the levels of justification, interactivity, and willingness to compromise.

In the first part of the paper, we analyzed the situational variables as perceived by the representatives. Based on the results of our analysis, we formulated theoretical expectations on their communicative behavior. We adopted a sequential approach and discussed the impact of the temporal variable on the quality of deliberation. The second part of the paper now turns to the speech acts of representatives. The analysis will permit us to verify the assumption that the situation and stage of decision-making matter for deliberative quality.

\subsection{Discourse Analysis}

In our study we focused on the two-pack debates in the ECON committee and the victims directive debates in joint sessions of the FEMM/LIBE committees. Both proposals were debated in three stages: exchange of views, presentation of the draft report, and consideration of amendments. In the following section, we assess the deliberative quality of the committee debates and discuss the impact of situational and temporal variables.

Our analysis takes into account the multidimensionality of deliberation. We did not expect the variables to equally influence all aspects of deliberation. The following section briefly summarizes the assumptions about the impact of these variables on deliberation.

We expected situational variables to matter for justification, respect, and willingness to compromise. We expected the overall level of deliberation to be higher in the victims directive debate than in the twopack debate. Generally, the victims directive was perceived as a noncontroversial and less salient issue. The attention the broader public and the media pay to the topic was low, if not nonexistent. Representatives were expected to be free from external constraints and to be open for other arguments (respect). Because they did not have to account for particular interests, we assumed that they would emphasize general European interests (content of justification). In addition, there was an important risk of the Council's vetoing the issue of costs, which would strengthen representatives' willingness to seek compromise (constructive politics). In sum, we expected both topic-related variables and the veto variable to increase the level of deliberation with regard to respect, common-good orientation, and willingness to compromise.

By contrast, there were strong particular and national interests at stake with the two-pack. The topic is commonly perceived as very salient and MEPs were closely monitored by their national party, their government, and their European political group. In the debate on the two-pack, the overall quality of deliberation was expected to be relatively low. Representatives felt more constrained in the debate; it was difficult for them to neglect the demands of their voters and their principals. Accordingly, they were expected to focus on particular interests and to score low on the common-good indicator. In addition, they were probably less open when it came to the interests of other groups. Nevertheless, as with the victims directive, the Council's vetoing posed a major risk. We expected MEPs to aim at an agreement and compromise, even if the process was difficult, in order to strengthen Parliament's position in the bargaining process with the Council.

The temporal variable was expected to matter with regard to interactivity, justification, and willingness to compromise. For these three dimensions, deliberative quality was expected to improve over the three stages of debate. In this study, we made no distinction between the victims directive and the two-pack. As we argued, the situational and temporal variables affect different dimensions of deliberation. Hence, the scores for justification, respect, and compromising were expected to differ between the two debates, but the level of interactivity, justification, and compromising was expected to evolve in similar fashion. Both debates were expected to improve from the first to the third debate with regard to these three dimensions.

The first debate aimed at exchanging information, and displayed a fairly low level of deliberation. In the second debate-the presentation and discussion of the draft report-the level of deliberation was expected to increase, with the rapporteurs justifying their proposals and representatives supplying commentary. At the final stage, we expected deliberation to be at the highest level. The debate was the last opportunity for the representatives to defend their position, which is why we expected the level of justification to be high. At this stage compromise also became central. To get their amendments adopted, representatives had to reach agreement with others, creating a high level of interactivity.

The next section turns to discourse analysis. The first part examines the situational dimension of 
deliberation and compares the overall level of deliberation between the two-pack and the victims directive debate. The section then turns to the decision-making process and examines the level of deliberation at each stage of debate.

\section{Empirical Findings}

The DQI was applied to the committee debates in the first reading on the two-pack and the victims directive. The committee debates are available for streaming and downloading on the website of the European Parliament [87]. Based on the video records, the debates were transcribed. Speeches in English, French and German were coded in the original language. For all other speeches, it was referred to the German translation. The results are reported in Table 1 [88].

The results indicate that the situation of decisionmaking influences the parliamentary debates and impacts on deliberative quality. As expected, the level of deliberation differed between the two debates with regard to justification and respect. Concerning the content of justification, the overall level of common good-orientation was higher in the victims directive debate (1.8 points) than in the two-pack debate (1.4 points). The difference holds in all three stages of decision-making, but the gap is most significant in the last debate. There, the level of common good-orientation is about 1.2 points in the two-pack debate, while the victims directive debate scores the highest possible value (2 points). Nevertheless, the results for the solidarity indicator attenuate the differences somewhat. In their speeches representatives in the Economic and Monetary Affairs Committee implicitly considered the consequences their demands have for the people concerned.

The two debates also differed on the level of respect. As expected, the overall level of respect was higher in the victims directive debate than in the twopack debate with regard to the three dimensions of respect. The differences are especially significant with respect towards other groups. In the victims directive debate, the mean score range is about 1.6 points versus a score about 1.07 points in the two-pack debate. The gap continues with the other two dimensions of respect: respect towards other participants, and respect towards the demands expressed by other participants. In general, speeches in the two-pack debate were neutral but not expressly respectful. By contrast, the overall level of respect was high in the victims directive debate.

In sum, the deliberative qualities of the debates differ from each other as expected. Surprisingly, however, there were more attempts to compromise in the two-pack debate, with a mean score of about 1.23 points for the two-pack debate versus 1.03 points for the victims directive debate. As we argued, the vetopower of the Council created pressure on participants to compromise in the two-pack debate and in the victims directive debate. But the de facto veto risk was more significant in the two-pack debate because it touched strong national interests. Moreover, the two-pack debate was more controversial than the victims directive debate. Hence, the necessity to compromise was higher in the two-pack debate than in the victims directive debate (where there was general agreement from the beginning of the legislative process).

Concerning the situational variables, our basic assumptions were confirmed. Particular interests played a major role in the debate on European governance, and the level of common good and respect were lower in the committee debate. By contrast, victims' rights were perceived as uncontroversial, universal rights. As expected, representatives justified their arguments by reference to the common-good and displayed mutual respect. The veto-power of the Council strengthened the compromise-orientation in both debates, especially the one on the two-pack, where the veto risk was more important.

We expected the quality of deliberation to improve in the decision-making process, regardless of the situation. The temporal variable was assumed to influence the dimensions of interactivity, justification andas the veto variable - the willingness to compromise. This study focuses on the average score of deliberation, taking both debates together. Table 2 presents the average values for the deliberative quality of both debates.

These findings support the main assumption according to which the quality of deliberation improves during the decision-making process. As expected, the overall level of deliberation is lower in the first debate and increases in the following debates.

With regard to the differences between the exchange of views and the following two debates, the results indicate that the exchange of view is aimed at exchanging information and making preliminary statements. Accordingly, the general quality of deliberation is relatively low in the first debate. The result was found with each of the three dimensions: the debates were not interactive, the level of justification was low, and there were no attempts to compromise. In the following debate, when the report was presented, participants started to exchange arguments, justify their points of view, and make initial compromises. The level of justification increased from a relatively low mean score of about 1.39 points at the beginning to a value of 2 points in the second debate and 2.19 points in the last debate. The mean score of the "constructive politics" indicator improved by 0.8 points from the first debate ( 0.57 points) to the second and third debate (1.38 points). 
Table 1. Deliberative quality.

\begin{tabular}{|c|c|c|c|c|c|c|c|c|c|c|c|}
\hline & \multirow{2}{*}{$\mathrm{N}$} & \multirow{2}{*}{$\begin{array}{c}\text { Participation* } \\
\text { Interruption }\end{array}$} & \multirow{2}{*}{$\begin{array}{c}\begin{array}{c}\text { Level of } \\
\text { justification }\end{array} \\
\text { Level }\end{array}$} & \multicolumn{2}{|c|}{ Content of justification } & \multicolumn{3}{|c|}{ Respect } & \multicolumn{2}{|c|}{ Interactivity } & \multirow{2}{*}{$\begin{array}{c}\text { Constructive } \\
\text { politics }\end{array}$} \\
\hline & & & & $\begin{array}{l}\text { Common } \\
\text { good }\end{array}$ & Solidarity & Participants & $\begin{array}{l}\text { Other } \\
\text { groups }\end{array}$ & Demands & Part. & Arg. & \\
\hline ECON & & $0-1$ & $0-4$ & $0-2$ & $0-3$ & $0-2$ & $0-2$ & $0-2$ & $0-1$ & $0-2$ & $0-4$ \\
\hline $\begin{array}{l}\text { Exchange of } \\
\text { views }\end{array}$ & 8 & 1 & 1.88 & 1.5 & 1.75 & 1.25 & 1 & 1.13 & 0.63 & 0.38 & 0.5 \\
\hline $\begin{array}{l}\text { Presentation of } \\
\text { draft report }\end{array}$ & 17 & 1 & 2.47 & 1.53 & 1.88 & 1.35 & 1 & 1.18 & 0.94 & 1.47 & 1.29 \\
\hline $\begin{array}{l}\text { Consideration of } \\
\text { amendments }\end{array}$ & 18 & 1 & 2.25 & 1.22 & 1.89 & 1.44 & 1.17 & 1.17 & 1 & 1.28 & 1.5 \\
\hline Overall quality** & 43 & 1 & 2.26 & 1.40 & 1.86 & 1.37 & 1.07 & 1.16 & 0.91 & 1.19 & 1.23 \\
\hline
\end{tabular}

FEMM/LIBE

\begin{tabular}{|c|c|c|c|c|c|c|c|c|c|c|c|}
\hline $\begin{array}{l}\text { Exchange of } \\
\text { views }\end{array}$ & 15 & 0.94 & 1.14 & 1.67 & 1.87 & 1.07 & 1.47 & 1 & 0.33 & 0.27 & 0.6 \\
\hline $\begin{array}{l}\text { Consideration of } \\
\text { draft report }\end{array}$ & 12 & 1 & 1.33 & 1.83 & 1.83 & 1.67 & 1.75 & 1.42 & 0.92 & 1.08 & 1.5 \\
\hline $\begin{array}{l}\text { Consideration of } \\
\text { amendments }\end{array}$ & 8 & 1 & 2.25 & 2 & 1.75 & 1.88 & 1.63 & 1.25 & 1 & 1.63 & 1.13 \\
\hline Overall quality** & 35 & 0.97 & 1.43 & 1.80 & 1.83 & 1.46 & 1.60 & 1.2 & 0.69 & 0.89 & 1.03 \\
\hline
\end{tabular}

Notes: *All numbers are mean values. The higher the code assigned to the speech acts for each dimension, the better the deliberative quality. $* *$ The overall quality is calculated based on the speech acts of all three debates taken together. Source: own calculation. 
Table 2. Stages of deliberation.

\begin{tabular}{|c|c|c|c|}
\hline & $\begin{array}{l}\text { Exchange of } \\
\text { views* }\end{array}$ & $\begin{array}{l}\text { Presentation of } \\
\text { draft report }\end{array}$ & $\begin{array}{c}\text { Consideration of } \\
\text { amendments }\end{array}$ \\
\hline Participation & 0.96 & 1 & 1 \\
\hline Level of justification & 1.39 & 2 & 2.19 \\
\hline \multicolumn{4}{|l|}{ Content of justification } \\
\hline Common good & 1.61 & 1.66 & 1.46 \\
\hline Solidarity & 1.83 & 1.86 & 1.85 \\
\hline \multicolumn{4}{|l|}{ Respect } \\
\hline Participants & 1.13 & 1.48 & 1.58 \\
\hline Other groups & 1.30 & 1.31 & 1.31 \\
\hline Demands & 1.04 & 1.28 & 1.19 \\
\hline \multicolumn{4}{|l|}{ Interactivity } \\
\hline Towards participants & 0.43 & 0.93 & 1 \\
\hline Towards arguments & 0.30 & 1.31 & 1.38 \\
\hline Constructive politics & 0.57 & 1.38 & 1.38 \\
\hline Overall quality of deliberation** & 1.06 & 1.46 & 1.43 \\
\hline
\end{tabular}

The interactivity also increased during the three debates with regard to both participants and arguments. The results indicate that the two stages of debate clearly fulfilled different functions, confirming the theoretical considerations discussed above. In the first debate participants informed each other of the proposals and their points of view; in the second debate participants sought to exchange arguments with the aim of convincing other participants.

The evolution was particularly important at the beginning of deliberation but diminished in the later two debates. While the level of justification and interactivity increased by about 0.7 points, the willingness to compromise stagnated at 1.38 points. This indicates that compromise was just as important in the second debate (the presentation of the draft report) as in the final debate (when amendments were considered).

The compromise may also have taken place outside official committee debates, in informal negotiations between the shadow rapporteurs. In this case, the compromises would already have been considered before the presentation of the amendments in the committee meetings. During the presentation of amendments the shadows would then insist on their positions and justify them carefully to show voters that they had acted in their interests, especially if their amendments had not been taken into account in the compromises. As an official stated in the interviews, the submission of amendments opens the floor for bargaining processes: "on Monday, the amendments will be submitted. Then we will try to enter into negotiations, of course" [89].
In this view, deliberation takes place in the second meeting; the third session opens negotiations between entrenched positions. To make a definitive conclusion, further research is needed.

\section{Conclusion}

In this paper we analyzed the quality of deliberation in European Parliament committees. We argued that communication in committees is normatively framed by two antagonistic ideals, deliberation (common good orientation) and responsiveness (particular interest orientation). These ideals influence the communicative behavior of representatives and hence impact on the quality of deliberation. The first part of the paper discussed the impact of the situational variables on the quality of deliberation. Next we identified three stages of communication in the deliberative process with distinctive profiles of deliberative quality. As we argued, these stages can be likened to the three stages of the decision-making process in European parliament committees.

Based on a speech act analysis, we examined the committee debates of two distinctive decision-making processes. In both cases, we looked at the complete committee debates, from the exchange of views to the consideration of amendments. The empirical data support the assumptions regarding the impact of situational and temporal variables. As we expected, at all three stages the level of deliberation differed in both cases, especially on the content of justification and the level of respect. Our findings indicate that the 
situation of decision-making matters for the debate: the higher the perceived salience and publicity of a topic and the more particular the demands, the lower the quality of deliberation for these dimensions. In addition, a second general variable was introduced: the veto variable. We assumed that the threat of a Council veto would improve the deliberative quality of the debates in the committees, and favor the willingness to compromise of the participants. As our analysis shows, there were more de facto attempts to compromise in the debate on the two-pack, where the risk of a Council veto was higher than in the case of the victims directive. Our interviews also confirm the importance of an external threat for the quality of deliberation in committee debates.

In addition, our findings show that deliberative quality varied across the duration of debate. In both committee debates, the quality of deliberation increased during the three stages of decision-making process, even though the scores differed on the two debates,

\section{References and Notes}

1. Léa Roger writes her dissertation on "How to agree: Deliberation and negotiation in EP committees". The data in this paper has been collected and examined as part of her dissertation.

2. Mutz DC. Is Deliberative Democracy a Falsifiable Theory? Annual Review of Political Science. 2008;11: 521-538.

3. Mill JS. Representative Government. North Terrace, Australia: University of Adelaide Library; 2012. Available from: http://ebooks.adelaide.edu.au/m/mill/ john_stuart/m645r/complete.html\#chapter5 (accessed on 25 July 2013).

4. Steenbergen $M R$, Bächtiger $A$, Spörndli M, Steiner J. Measuring Political Deliberation: A Discourse Quality Index. Comparative European Politics. 2003;1(1):21-48.

5. Empirical studies on deliberation have mainly focused on institutional and sociopsychological variables (see for example $[13,16]$ ).

6. Proposal for a regulation of the European Parliament and of the Council on common provisions for monitoring and assessing draft budgetary plans and ensuring the correction of excessive deficit of the Member States in the euro area COM (2011) 821 final, Brussels, 23.11.2011; Proposal for a regulation of the European Parliament and of the Council on the strengthening of economic and budgetary surveillance of Member States experiencing or threatened with serious difficulties with respect to their financial stability in the euro area COM (2011) 819 final, Brussels, 23.11.2011.

7. Proposal for a directive of the European Parliament and the Council establishing minimum standards on the rights, support and protection of victims of crime. COM (2011) 275 final, Brussels, 18.05.2011.

8. Plenary debates in the European Parliament are with the situation of decision-making influencing the quality of deliberation. Further large-scaled studies are needed to confirm our findings. Our study demonstrates the importance of going beyond the comparative analysis of institutional variables by focusing on situational and temporal variables.

\section{Acknowledgements}

The development of this paper has benefited from comments provided by the participants at the 22nd IPSA Word Congress, Madrid, July 2012 (Workshop Political Theory) and the spring meeting of the DVPW Section of Political Theory, Hannover, March 2013, as well as from comments provided by the anonymous reviewers. We thank all interviewees for sharing their time and information. We are grateful to Seraina Pedrini for helpful comments on coding and to Tobias Gerlach for cross-coding.

highly formal. The real debates take place in committees.

9. Costa O. Le Parlement européen, assemblée délibérante. Brussels, Belgium: Editions de l'Université de Bruxelles; 2001.

10. Corbett R, Jacobs F, Shackleton M. The European Parliament. 8th ed. London, UK: John Harper Publishing; 2011.

11. Judge D, Earnshaw D. The European Parliament. 2nd ed. Basingstoke, UK: Palgrave Macmillan; 2008.

12. Gutmann A, Thompson DF. Democracy and Disagreement. Cambridge, MA, USA: The Belknap Press; 1996.

13. Steiner J, Bächtiger A, Spörndli M, Steenbergen MR. Deliberative Politics in Action. Analyzing Parliamentary Discourse. Cambridge, MA, USA: Cambridge University Press; 2004.

14. Habermas J. Between Facts and Norms. Contributions to a Discourse Theory of Law and Democracy. Cambridge, MA, USA: Polity Press; 1996.

15. Manin B. On Legitimacy and Political Deliberation. Political Theory. 1987;15(3):338-368.

16. Sunstein CR. The Law of Group Polarization. In: Fishkin J, Laslett $\mathrm{P}$, editors. Debating Deliberative Democray. Oxford, UK: Blackwell Publishing; 2003. pp. 80-101.

17. Bohman J. Public Deliberation: Pluralism, Complexity and Democracy. Cambridge, MA, USA: MIT Press; 1996.

18. Dryzek JS. Deliberative Democracy and Beyond: Liberals, Critics, Contestations. Oxford, UK: Oxford University Press; 2000.

19. Bohman J. Survey Article: The Coming of Age of Deliberative Democracy. Journal of Political Philosophy. 1998;6(4):400-425.

20. Chambers S. Behind closed Doors: Publicity, Secrecy, and the Quality of Deliberation. Journal of Political Philosophy. 2004;12(4):389-410. 
21. Thompson DF. Deliberative Democratic Theory and Empirical Political Science. Annual Review of Political Sciences. 2008;11:497-520.

22. Schaal GS, Ritzi C. Empirische Deliberations forschung. MPIfG Working Paper 9/09. Cologne, Germany: Max Planck Institute for the Study of Societies; 2009.

23. Sanders LM. Against Deliberation. Political Theory. 1997;25(3):347-376.

24. Young IM. Activist Challenges to Deliberative Democracy. Political Theory. 2001;29(5):670-690.

25. Mansbridge JJ, Bohman J, Chambers S, Estlund D, Føllesdal A, Fung A, Lafont C, Manin B, Martí JL. The Place of Self-Interest and the Role of Power in Deliberative Democracy. Journal of Political Philosophy. 2010;18(1):64-100.

26. Bächtiger A, Niemeyer S, Neblo M, Steenbergen MR, Steiner J. Symposium: Toward More Realistic Models of Deliberative Democracy. Disentangling Diversity in Deliberative Democracy: Competing Theories, Their Blind Spots and Complementarities. The Journal of Political Philosophy. 2010;18(1):32-63.

27. Sartori G. Concept Misformation in Comparative Politics. The American Political Science Review. 1970;64(4):1033-1053.

28. Steiner J. Concept stretching: The case of deliberation. European Political Science. 2008;7(2):186-90.

29. Dahl RA. Democracy and Its Critics. New Haven, CT, USA: Yale University Press; 1989.

30. Przeworski A, Stokes SC, Manin B, editors. Democracy, Accountability and Representation. Cambridge, UK: Cambridge University Press; 1999.

31. "How can a representative assembly work for good if its members can be bought, or if their excitability of temperament, uncorrected by public discipline or private self-control, makes them incapable of calm deliberation, and they resort to manual violence on the floor of the House, or shoot at one another with rifles?" (see [3]).

32. Manin B. The Principles of Representative Government. Cambridge, UK: Cambridge University Press; 1997.

33. Berger $P$, Luckmann T. Die gesellschaftliche Konstruktion der Wirklichkeit: Eine Theorie der Wissenssoziologie. Frankfurt a.M., Germany: Fischer Verlag; 1969.

34. Hix S. Parliamentary Behavior with Two Principals. Preferences, Parties, and Voting in the European Parliament. American Journal of Political Science. 2002; 46(3):688-698.

35. Müller WC. Political parties in parliamentary democracies. Making delegation and accountability work. European Journal of Political Research. 2000;37 (3):309-333.

36. Strøm K. Delegation and Accountability in Parliamentary Democracies. European Journal of Political Research. 2000;37(3):261-289.

37. Shapiro I. Enough of Deliberation. Politics Is about Interests and Power. In: Macedo S, editor. Delib- erative Politics: Essays on Democracy and Disagreement. Oxford, UK: Oxford University Press; 1999. pp. 28-38.

38. Downs A. An Economic Theory of Democracy. Stanford, CA, USA: Harper; 1957.

39. For a more detailed discussion of the situational variables and for first empirical analysis on their impact on the quality of deliberation, see also [53].

40. Cohen J. Deliberation and Democratic Legitimacy. In: Hamlin A, Pettit P, editors. The Good Polity. Normative Analysis of the State. Oxford, UK: Blackwell; 1989. pp. 17-34.

41. Bächtiger A, Hangartner D. When Deliberative Theory Meets Empirical Political Science, Theoretical and Methodological Challenges in Political Deliberation. Political Studies. 2010;58(4):609-629.

42. Lord C, Tamvaki D. The Politics of Justification? Applying the 'Discourse Quality Index' to the Study of the European Parliament. RECON Online Working Paper 2011/3. Oslo, Norway: ARENA-Centre for European Studies; 2011.

43. Fearon JD. Deliberation as Discussion. In: Elster J, editor. Deliberative Democracy. Cambridge, UK: Cambridge University Press; 1998. pp. 44-68.

44. Goodin RE. Sequencing Deliberative Moments. Acta Politica. 2005;40(2):182-196.

45. Bächtiger A, Pedrini S, Ryser M. Analyzing Political Process: Deliberative Standards, Discourse Types and Sequenzialization. Paper presented at the Conference "Democracy as Idea and Practice", Oslo, Norway, 1415 January 2010.

46. National Coalition for Dialogue \& Deliberation. Resource Guide on Public Engagement. Boiling Springs, PA, USA: National Coalition for Dialogue \& Deliberation; 2010. Available from: http://www.ncdd.org/files/NCDD 2010_Resource_Guide.pdf (accessed on 25 July 2013).

47. Heierbacher S. Dialog and Deliberation. In: Holman $P$, Devane T, Cady S, editors. The Change Handbook. San Francisco, CA, USA: Berrett-Koehler Publishers; 2007. pp. 102-117.

48. Heierbacher ([47], p. 8) differentiates between "exploration", "conflict transformation", and "decisionmaking" with corresponding modes of communication and communicative actions. Arguing from an ideal type perspective, these are different and distinct stages that vary over time. In reality "mutual understanding" and "justification" may happen at the same time, but to varying degrees. Empirically, we argue that each stage is dominated by one mode of communication.

49. Curato N. A sequential analysis of democratic deliberation. Acta politica. 2012;47(4):423-442. Nicole Curato distinguishes between "confrontation stage", "opening stage", "argumentation stage", and "concluding stage".

50. Bächtiger A, Shikano S, Pedrini S, Ryser M. Measuring Deliberation 2.0: Standards, Discourse Types, and Sequentialization, 2010. Available from: http://ash.harv ard.edu/extension/ash/docs/baechtiger.pdf (accessed on 14 June 2012). 
51. Steiner J. The Foundations of Deliberative Democracy. Empirical Research and Normative Implications. Cambridge, MA, USA: Cambridge University Press; 2012.

52. Bächtiger A, Pedrini S, Ryser M. Prozessanalyse politischer Entscheidungen: Deliberative Standards, Diskurstypen und Sequenzialisierung. In: Behnke J, Bräuninger $T$, Shikano $S$, editors. Jahrbuch für Handlungs- und Entscheidungstheorie. Band 6. Schwerpunkt Neuere Entwicklungen des Konzepts der Rationalität und ihre Anwendungen. Wiesbaden, Germany: VS Verlag für Sozialwissenschaften; 2010. pp. 193-226.

53. Roger L. Analyzing Parliamentary Communication. The Impact of Role Orientations on MEPs Discoursive Behavior in Committee Debates. Paper presented at the Inaugural General Conference of the ECPR Standing Group on Parliaments, Dublin, Ireland, 24-27 June 2012.

54. Roger L. Deliberation im Europäischen Parlament: Der Einfluss von Rollenorientierungen auf das Kommunikationsverhalten von Abgeordneten. In: Bächtiger A, Linhart Eric, Shikano S, editors. Jahrbuch für Handlungs- und Entscheidungstheorie. Bd. 9: Räumliche Modelle der Politik. Wiesbaden, Germany: VS Verlag für Sozialwissenschaften; Forthcoming.

55. Landwehr C. Discourse and Coordination. Modes of Interaction and their Roles in Political Decision-Making. The Journal of Political Philosophy. 2010;18(1): 101-122.

56. It is reasonable to expect interactions between situational and temporal variables. But since this interaction cannot be measured, this paper focuses on the independent influence of situational and temporal variables on the particular dimensions of deliberation.

57. The whole process is accompanied by informal meetings between the rapporteur(s) and shadow rapporteurs. These meetings are of key importance, as they permit open discussions and private discussions behind closed doors. Unfortunately, because meetings are informal and protocols do not exist, we do not include them in our analysis.

58. On the two-pack, we conducted ten interviews with MEPs and ten European Parliament officials (political group advisors, MEP assistants, Members of the Secretariat). On the victims directive, interviews with nine MEPs and eleven EP officials were conducted. The interviews took place in the European Parliament in Brussels and Strasbourg from January to April 2012 and lasted between 20 minutes and one hour.

59. McElroy G. Committee Representation in the European Parliament. European Union Politics. 2006;7 (1):5-29.

60. Neuhold C. The "Legislative Backbone" keeping the Institution upright? The Role of European Parliament Committees in the EU Policy-Making Process. European Integration online Papers. 2001;5(10). Available from: http://eiop.or.at/eiop/texte/2001-010a.htm (accessed from 25 July 2013).
61. Brack N, Costa O, Dri C. Structural and Political Consequences of Procedural Changes in the European Parliament. Paper presented at the Ninth Workshop of Parliamentary Scholars and Parliamentarians, Wroxton College, UK, 24-25 June 2010.

62 . The interviews with the EP officials permitted to complement the data; officials-especially group advisors and members of the secretariat-have a broad overview on the decision-making process. On sensitive variables (pressures exercised by the parties, say), officials can be expected to answer honestly.

63 . See the appendix for the questions relating to the situational variables.

64. Interview $n^{\circ} 52$, MEP.

65. Interview $n^{\circ} 38$, official.

66 . Interview $n^{\circ} 50$, MEP.

67. Interview $n^{\circ} 67$, official.

68. Interview $n^{\circ} 39$, official.

69. Interview $n^{\circ} 28$, MEP.

70. Interview $n^{\circ} 25$, MEP.

71. Interview $n^{\circ} 61$, MEP, $n^{\circ} 28$, MEP.

72. Interview $n^{\circ} 40$, official; Interview $n^{\circ} 75$, official.

73. Interview $n^{\circ} 54, M E P$; Interview $n^{\circ} 31$, official.

74. Interview $n^{\circ} 27$, MEP.

75. Interview $n^{\circ} 66$, official.

76. Interview $n^{\circ} 54$, MEP; Interview $n^{\circ} 40$, official; Interview $n^{\circ} 21$, official.

77. Interview $n^{\circ} 35$, assistant of the interviewed MEP.

78. Interview $n^{\circ} 19$, official; Interview $n^{\circ} 34$, official; Interview $n^{\circ} 57$, official.

79. Interview $n^{\circ} 73$, MEP.

80. Interview $n^{\circ} 34$, official.

81. Interview $n^{\circ} 21$, official.

82. Statement by Philippe Lamberts (Greens/EFA), Exchange of views on the two-pack, ECON committee, original speech; 9 January 2012.

83. Statement by Marianne Thyssen (EPP), Exchange of views on the two-pack, ECON committee, English interpretation; 9 January 2012.

84. Statement by Carl Halgund (ALDE), Presentation of the draft reports on the two-pack, ECON committee, original speech; 28 February 2012.

85. Interview $n^{\circ} 31$, official.

86. Statement by Mikael Gustafsson, Consideration of amendments on the victims directive, LIBE/FEMM committee, English translation; 21 March 2012.

87. Website of the European Parliament. Available from: http://www.europarl.europa.eu/ep-live/en/commi ttees/search (accessed on 13 July 2012).

88. The speeches were partly double coded: in ECON, 33\% of the speeches were double coded with a total rate of coder agreement of $95 \%$ of the indicators. In FEMM/LIBE, $62 \%$ of the speeches were double coded with a rate of coder agreement of $98,7 \%$ of the indicators.

89. Interview $n^{\circ} 39$, official. 


\section{Appendix 1: Qualitative Questionnaire}

\section{Topic of debate}

First of all, I would like to ask you to give me some more information on (the topic)...

1. Could you please identify the main positions on the topic?

2. What are the main interests at stake?

Follow up: What are the main conflicting points?...And the main cleavages?

\section{Role of the political party/political group}

I would now like to turn to the role of your political party and your European political group...

3. Usually, political groups aim at agreeing on a common position. Could you please describe the opinion-building process in your own political group?

4. And what about the position of your national party?

5. Could you please describe the role of your political group in the decision-making process? Follow up: What about the role of your national party?

6. Members of the same political groups may disagree with each other on certain topics. Generally speaking, how do political groups deal with eventual disagreements?

7. And in (member state), with the national party? Do people sometimes get recommendations/instructions from their party on what position to defend?

8. And on (the topic). Do members of your group agree with each other? What about within your party?

9. What role do lobbyists and interest groups play in the decision-making process? Follow up: In general, how influential are they?

\section{Publicity}

10. How is the (topic) perceived in the European public opinion? Follow up:....and in your Member State? 


\section{Appendix 2: Discourse Quality Index}

\section{Participation}

1a-Participation (constraints)

(0) The speaker indicates that he or she is constrained.

(1) The speaker does not indicate that he or she is constrained by the behavior of other participants.

Level of justification

(0) $X$ should be done but no reason is given

(1) reason $Y$ is given why $X$ should or should not be done but no linkage is made

(2) linkage is made why one should expect that $X$ contributes to or detracts from $Y$

(3) two complete justifications are given (either for the same demand or for two different demands)

(4) a sophisticated justification is given

\section{Content of Justification}

3a-Common good

(0) The speaker refers to the interests of their constituents/their country or to sectoral interests.

(1) The speaker does not refer to any interests.

(2) The speaker refers to European or universal interests.

\section{$3 b$-Solidarity}

(0) The speaker opposes a proposition important to some people without considering negative consequences his position may have for these people.

(1) The speaker defends a certain position without considering negative consequences his position may have for other people.

(2) The speaker implicitly considers the interests of all people concerned.

(3) The speaker explicitly considers the interests of different people concerned.

\section{Respect}

4a-Respect toward other participants

(0) The speaker personally attacks other participants.

(1) The speaker does not refer or refers in a neutral way to other participants.

(2) The speaker positively refers to other participants.

\section{$4 b-$ Respect toward groups that are to be helped through policies}

(0) The speaker makes negative statements about the groups.

(1) The speaker makes no explicitly negative statements; nor does the speaker make explicit positive statements about the groups.

(2) The speaker makes at least one explicitly positive statement about the groups.

\section{Interactivity}

5a-Reference to other participants

(0) Participants do not refer to other participants.

(1) Participants refer to other participants.

\section{$5 b$-Reference to other participants}

(0) Participants do not refer to other participants' arguments.

(1) Participants refer to other participants' arguments but do not discuss them.

(2) Participants refer to other participants' arguments and discuss them.

Constructive politics

(0) The speaker sits on his/her positions. There is no attempt at compromise, reconciliation, or consensus building.

(1) The speaker signals willingness to compromise.

(2) The speaker makes a mediating proposal that does not fit the current agenda but belongs to another agenda.

(3) The speaker makes an appeal for consensus or compromise.

(4) The speaker makes a mediating proposal that fits the current agenda. 


\section{Appendix 3: List of Qualitative Interviews}

1. Two-Pack

Members* of the ECON committee:

1. Interview $n^{\circ} 17,14.02 .2012$, EP Strasbourg.

2. Interview $n^{\circ} 25,16.02 .2012$, EP Brussels.

3. Interview $n^{\circ} 28,20.02 .2012$, EP Brussels.

4. Interview $n^{\circ} 36,06.03 .2012$, EP Brussels.

5. Interview ${ }^{\circ} 50,13.03 .2012$, EP Strasbourg.

6. Interview $n^{\circ} 51,14.03 .2012$, EP Brussels.

7. Interview $n^{\circ} 53,14.03 .2012$, EP Strasbourg.

8. Interview $n^{\circ} 52,14.03 .2012$, EP Strasbourg.

9. Interview $n^{\circ} 61,21.03 .2012$, EP Strasbourg.

10.Interview n70, 27.03.2012, EP Brussels.

EP officials ECON committee:

1. Interview $n^{\circ} 20,15.02 .2012$, EP Strasbourg.

2. Interview $n^{\circ} 32,02.03 .2012$, EP Brussels.

3. Interview $n^{\circ} 30,02.03 .2012$, EP Brussels.

4. Interview $n^{\circ} 38,06.03 .2012$, EP Brussels.

5. Interview $n^{\circ} 39,07.03 .2012$, EP Brussels.

6. Interview $n^{\circ} 12,13.03 .2012$, EP Strasbourg.

7. Interview $n^{\circ} 67,22.03 .2012$, EP Brussels.

8. Interview $n^{\circ} 64,22.03 .2012$, EP Brussels.

9. Interview $n^{\circ} 65,22.03 .2012$, EP Brussels.

10.Interview $n^{\circ} 76,30.03 .2012$, EP Brussels.

2. Victims directive

Members of the LIBE committee:

1. Interview $n^{\circ} 23,26.02 .2012$, EP Strasbourg.

2. Interview $n^{\circ} 27,28.02 .2012$, EP Brussels.

3. Interview $n^{\circ} 43,08.03 .2012$, EP Brussels.

4. Interview $n^{\circ} 54,14.03 .2012$, EP Strasbourg.

5. Interview $n^{\circ} 71,27.03 .2012$, EP Brussels.

Members of the FEMM committee:

1. Interview $n^{\circ} 22,16.02 .2012$, EP Strasbourg.

2. Interview $n^{\circ} 35,06.03 .2012$, EP Brussels.

3. Interview $n^{\circ} 33,06.03 .2012$, EP Brussels.

4. Interview $n^{\circ} 73,28.03 .2012$, EP Brussels.

EP officials LIBE committee:

1. Interview $n^{\circ} 29,10.03 .2012$, EP Brussels.

2. Interview $n^{\circ} 57,15.03 .2012$, EP Strasbourg.

3. Interview $n^{\circ} 66,22.03 .2012$, EP Brussels.

4. Interview $n^{\circ} 40,22.03 .2012$, EP Brussels.

5. Interview $n^{\circ} 75,29.03 .2012$, EP Brussels.

6. Interview $n^{\circ} 21,15.02$. 2012, EP Strasbourg.

EP officials FEMM committee:

1. Interview $n^{\circ} 19,15.02 .2012$, EP Brussels.

2. Interview $n^{\circ} 31,02.03 .2012$, EP Brussels.

3. Interview $n^{\circ} 34,06.03 .2012$, EP Brussels.

4. Interview $n^{\circ} 62,22.03 .2012$, EP Brussels.

5. Interview $n^{\circ} 77,30.03 .2012$, EP Brussels.

Note: *Interviews were held with rapporteurs, shadow rapporteurs, coordinators, and committee members (MEPs), as well as with Members of the Secretariat, group advisors, and MEP assistants (EP officials). The article indicates whether the information stems from an MEP or an official, but withholds further information to guarantee the anonymity of the interviewees. 